\title{
Working Capital Management in Ancillary's of BHEL, Tiruchirappalli, Tamil Nadu
}

\author{
D. Muthusamy ${ }^{1}$ and M. Sathish Kumar ${ }^{2}$ \\ ${ }^{1}$ Associate Professor, PG \& Research Department of Commerce, \\ Kurinji College of Arts and Science, Tiruchirappalli, Tamil Nadu \\ ${ }^{2}$ Ph.D. Research Scholar, Assistant Professor, Department of Commerce (SFC), \\ Urumu Dhanalakshmi College, Tiruchirappalli, Tamil Nadu \\ E-Mail: sathishkumar853@yahoo.co.in
}

\begin{abstract}
The amount of profit largely depends on the magnitude of sales. However sales do not converted into cash instantaneously in this concern. There is always a time gap between the sales of goods and receipt of cash. Working capital is required for this period in order to sustain the conversion activity. In case adequate working capital is not available for the period, the company will not be in a position to sustain the sales since it may not be in a position to purchase raw materials, payment of wages and other operating expenses that required for manufacturing the goods that to be sold. It is a descriptive that capital which is to consider the difference between book value of current asset and current liabilities. This study has to analysis the working capital management in ancillary units of BHEL.
\end{abstract}

Keywords: Working Capital Management, Ancillary Unit, Sales

\section{INTRODUCTION}

Working capital refers to the firm's total investment on current asset to current liabilities. The term working capital is the amount of funds necessary for the cost of operating the enterprise. Working capital is a going concern is a revolving of funds it consists of cash receipts from sales, which are used to cover the cost of operation. There are two concepts of working capital- gross working capital and net working capital. Gross working capital refers to the firm's investment in current assets. Current assets are the asset which can be converted in to cash within the accounting year and includes cash, short term securities, debtors, bills receivable and stock.net working capital refers to the difference between current asset and current liabilities. Current liabilities are those claims of outsiders which are expected payment with in accounting period and include creditors, bills payable and outstanding expenses. Net working capital can be positive or negative. Positive net working capital will arise when current asset exceeds current liabilities. Negative working capital can be occurred when current liabilities are in excessive of current assets. It is a descriptive of that capital which capital is to consider it as the difference between book value of current asset and current liabilities.

\section{OBJECTIVES OF THE STUDY}

1. To analysis the trend in investment in working capital and its components of the Ancillary Unit.
2. To analysis the efficiency of inventories and its components and receivable in the Ancillary Unit.

3. To study the method of financing of working capitals budgeted in Ancillary Unit.

4. To draw findings and make conclusions on the basis of the above analysis.

\section{METHODOLOGY}

The primary methods are used for collection of ancillary's details during period of study. The annual reports are used as secondary which is audited and some updated information collected in news papers and website of BHEL about the concern. The researcher has taken an ancillary out of twelve ancillaries namely Devi Engineering Industry situated in nearby BHEL Trichy which getting orders directly from out sourcing.

\section{SCOPE OF THE STUDY}

Even though the efficiency of an organization and its management would involve a study of all the functional aspects viz., production, sales, finance, personal, etc,... since it was felt that such a study though would be exhaustive would required a long time and large group of work men and money, due to constraints of time money and other factors.

\section{REVIEW OF LITERATURE}

Prasad 2001 conducted a research Study on the Working Capital Management in paper Industry. His samples consisted of 21 paper mills from large, medium and small scale industry for a period of 10 years. He reported that the chief executives properly recognized the role of efficient use of working capital in liquidity and profitability, but in practice they could not achieve it. The study also revealed that fifty percent of the executives followed budgetary method in planning working capital and working capital management was inefficient due to sub-optimum utilization of working capital.

Ghosh and Maji, 2003 in this paper made an attempt to examine The Efficiency of Working Capital Management of the Indian Cement Companies during 1992-1993 to 2001- 
2002. For measuring the efficiency of working capital management, performance, utilization, and overall efficiency indices were calculated instead of using some common working capital management ratios. Setting industry norms as target-efficiency levels of the individual firm, it also tested the speed of achieving that target level of efficiency by an individual firm during the period of study.

\section{DATA ANALYSIS AND INTERPRETATION}

TABLE I STATEMENT OF NETWORKING CAPITAL

\begin{tabular}{|c|c|c|c|}
\hline Year & $\begin{array}{c}\text { Current } \\
\text { Liabilities }\end{array}$ & $\begin{array}{c}\text { Current } \\
\text { Assets }\end{array}$ & $\begin{array}{c}\text { Networking } \\
\text { capital }\end{array}$ \\
\hline $2007-2008$ & 1461248.20 & 849169.51 & 612079 \\
\hline $2008-2009$ & 1665411.70 & 786529.75 & 878882 \\
\hline $2009-2010$ & 2528886.60 & 1330837.00 & 1198050 \\
\hline $2010-2011$ & 2239026.00 & 777464.16 & 1461562 \\
\hline $2011-2012$ & 2503474.00 & 509677.90 & 1993796 \\
\hline $2012-2013$ & 3456746.36 & 1354653.00 & 2102093 \\
\hline \multicolumn{4}{|c|}{ Data Source: Annual Report } \\
\hline
\end{tabular}

The table I shows the company's networking capital for the past five years. The net working capital is important to buy raw materials and more use of funds for a particular job. This ratio shows increasing trend for the study period. The ratio shows efficiency in working capital.

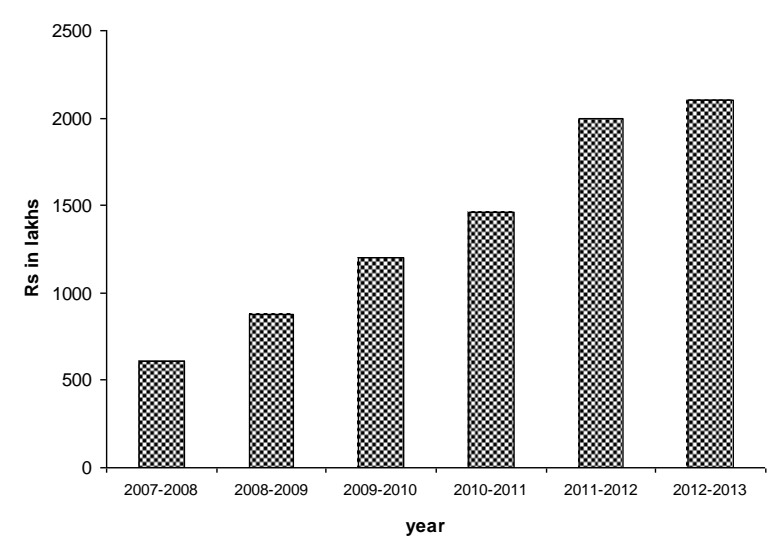

Fig. 1 Networking Capital

TABLE II SALES TO WORKING CAPITAL

\begin{tabular}{|c|c|c|c|c|c|}
\hline Year & Sales & Current Assets & Current Liabilities & Total & Ratio \\
\hline $2007-2008$ & 5588046.00 & 1461248.20 & 849169.51 & 612079 & 9.1 \\
\hline $2008-2009$ & 6902878.00 & 1665411.70 & 786529.75 & 878882 & 7.9 \\
\hline $2009-2010$ & 8746280.00 & 2528886.60 & 1330837.00 & 1198050 & 7.3 \\
\hline $2010-2011$ & 8778448.00 & 2239026.00 & 777464.16 & 1461562 & 6.0 \\
\hline $2011-2012$ & 11728810.00 & 2503474.00 & 509677.90 & 1993796 & 5.9 \\
\hline $2012-2013$ & 1231360.00 & 3456746.36 & 1354653.00 & 2102093 & 0.6 \\
\hline
\end{tabular}

The table II shows that the turnover to working capital for the study period has been taken by the researcher. The working capital is important to reduce the wastage of raw material and more use of funds for the particular job. This ratio is continuously decreasing for the past 6 year i.e. 20072008 it was 9.13 times and 0.6 times in 2012-2013. This shows, usage of the working capital towards sales has more efficiently during the study period

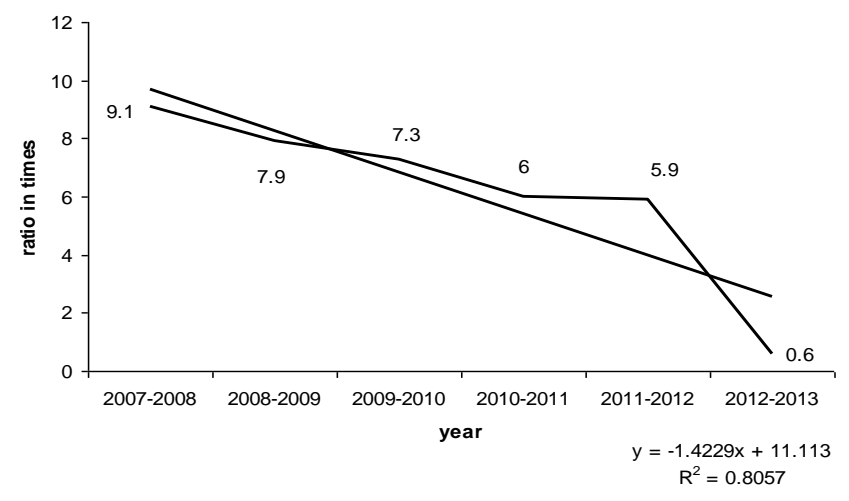

Fig. 2 Sales to Working Capital
TABLE III INVENTORY TO WORKING CAPITAL

\begin{tabular}{|c|c|c|c|}
\hline & & \multicolumn{2}{|c|}{ Amount in thousands } \\
\hline Year & Inventory & $\begin{array}{c}\text { Net } \\
\text { Working } \\
\text { Capital } \\
\end{array}$ & $\begin{array}{c}\text { Inventory to } \\
\text { Working } \\
\text { Capital } \\
\end{array}$ \\
\hline $2007-2008$ & 162000 & 612078.7 & 26 \\
\hline $2008-2009$ & 600385 & 878882 & 68 \\
\hline $2009-2010$ & 665000 & 1198049.6 & 56 \\
\hline $2010-2011$ & 725500 & 1461561.9 & 50 \\
\hline 2011-2012 & 304018 & 1793796.1 & 17 \\
\hline $2012-2013$ & 1626667 & 2102030 & 77 \\
\hline
\end{tabular}

The table III shows that Inventory to net working capital ratio was 26 times in the year 2007-2008. For the next year the ratio was increased to 68 times in 2008-2009, decreased to 56 times in 2009-2010 respectively. In the next year 2010-2011 it was increased to 50 times and in the next year 20012-2013, it was again decreased to 17 times. While comparing working capital with inventory the ratio shows the inventory efficiency of the concern. 


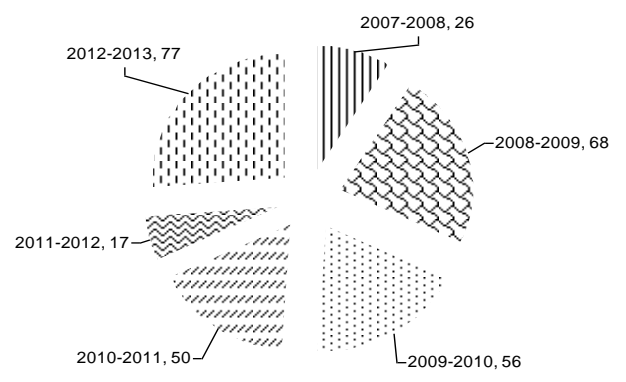

Fig. 3 Inventory to Working Capital

TABLE IV WORKING CAPITAL TO CURRENT LIABILITIES RATIO

\begin{tabular}{|c|c|c|c|}
\hline \multicolumn{1}{c}{ Year } & $\begin{array}{c}\text { Net Working } \\
\text { Capital }\end{array}$ & $\begin{array}{c}\text { Current } \\
\text { Liabilities }\end{array}$ & Ratio \\
\hline $2007-2008$ & 612078.70 & 849169.51 & 0.72 \\
\hline $2008-2009$ & 878882.00 & 786529.75 & 1.12 \\
\hline $2009-2010$ & 1198049.60 & 1330837.00 & 0.90 \\
\hline $2010-2011$ & 1461561.90 & 777464.16 & 1.88 \\
\hline $2011-2012$ & 1793796.10 & 509677.90 & 3.52 \\
\hline $2012-2013$ & 2102030.00 & 1354653.00 & 1.55 \\
\hline
\end{tabular}

The table IV reveals that, how the firm uses their working capital towards their current liabilities? Above table shows fluctuation in each and every year. But it goes high in 20112012 at 3.52 times, when compared to other years in study period. The ratio recorded minimum in 2007-2008 and 2009-2010 at 0.72 and 0.90 times respectively. This ratio shows the firm's instability in controlling the working capital towards current liabilities.

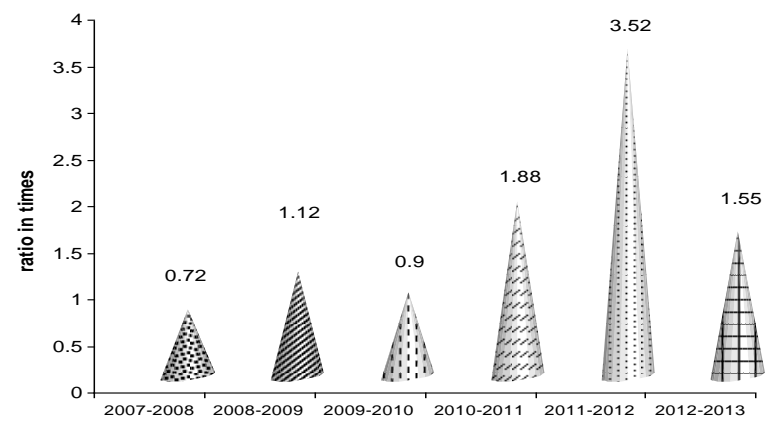

year

Fig. 4 Working Capital to Current Liabilities Ratio

\section{FINDINGS}

1. Most of the year, current ratio has reached the norms at $2: 1$. It shows there are ideal use of funds

2. The net profit ratio shows that the sales efficiency of the firm per rupee or sales. It shows more efficiency expected 2010-2011.
3. The material consumed ratio is higher and it is better for the concerns. The high conversion cost ratio indicates the concerns are better to utilize the expenses towards sales.

4. The asset turnover ratio shows that over trading of total asset during the year 2007-2008 and 2008-2009. The ratio for the remaining year shows the ideal capacity of the firms. The traditional standard ratio is two times.

5. The fixed asset turnover ratio shows that the asset are utilized by the firms were more efficiently and useful.

6. The sales to working capital ratio show the firms have inefficiency in using working capital.

7. The current asset to fixed asset ratio for the first three years the firms uses the asset more efficiently and in the remaining years the ratio shows minimum efficiency.

8. The sales to current asset ratio shows that the firms used the income more efficiently to utilize the current asset.

9. The working capital to current liability ratio shows the firm's instability in controlling the working capital.

10. Debtor turnover ratio clearly shows that ratio is inconsistent and continuous increasing. It shows efficiency in managing the debtors.

11. Average debt collection period shows in efficiency to collect the money from debtors or it shows liberal debt collection policy.

12. Inventory turnover ratio clearly shows that ratio is inconsistent and continuous decreasing. It shows inefficiency in managing the inventories.

13. The inventory holding period shows the firms position in maintaining inventory holding for less than 50 days.

14. While comparing working capital to the inventory ratio firm is in efficiency and more useful.

15. Working capital trend shows a continuous increasing in working capital.

16. The debtor to current asset ratio shows that firms utilized the funds from the debtors towards the current asset.

\section{LIMITATIONS}

The study was only made for six years from 2007-2008 to 2012-2013 any change made or occurred before or after this period has not been taken in to consideration. The working capital analysis was compared with similar firm in the same field.

\section{CONCLUSION AND RECOMMENDATION}

The study on working capital management was undertaken in the ancillary units of BHEL, Trichy for a period of five years from 2007-2008 to 2012-2013. By means of advancement of technology and the effectiveness of employee; it uplifts the firm to a tremendous growth. The firms have to increase the production and the workers. The analysis reflects that the companies possessing good in liquidity position. During the period of study there were a few ups and downs in the working capital management, but it did not affect the operation of the companies to a great 
extent. On the whole the working capital and analysis various ratios in ancillary units of BHEL, Trichy have been good. The companies have to analyze the working capital for each quarter to make the production more efficiency in future. It has to maintain the debtor collection period for the coming period. While in study period the concerns has shows fluctuation in working capital. The concerns have to analyze the cash budget for the coming period, to maintain the cash flow and the inventory turnover when order received from BHEL. The companies have to maintain the conversion charges income and make more jobs from the outsiders. The conversion cost of the concern is more efficient, so the concerns have to maintain the expenses relating to conversion income.

\section{REFERENCES}

[1] Audited report of ancillary unit of BHEL Trichy.

[2] Maheswari, S. N. reprint 2010, Elements of financial management.

[3] Foster G., (1986). Financial Statement Analysis, Prentice hall.

[4] Ghosh, S. K. \& Maji, S. G. (2003). Working Capital Management Efficiency: A study on Indian Cement Industry. ICWAI 1995, $1^{\text {st }}$ edition, 20-93.

[5] Hampton \& John J., (1977). Financial Decision Making. Ed.

[6] Prasad, R. (2005). Working Capital Management in Paper Industry. Finance India, 15(1), 185 -188.

[7] Rakesh Chandra Sharma. (1985). Financial Reporting in Public Enterprises. Sultan and Sons.

[8] Jain, S. P. \& Narang, K. L. (2000). Advanced Accountancy.

[9] Weston and Brigham, Managerial Finance, $5^{\text {th }}$ edition Al. 